\title{
Phytochemicals mediated signalling pathways and their implications in cancer chemotherapy: challenges and opportunities in phytochemicals based drug development : A review
}

Vivek Kumar Gupta, Reetika Singh and Bechan Sharma*

*Correspondence: sharmabi@yahoo.com

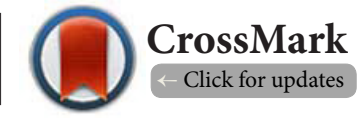

Department of Biochemistry, Faculty of Science, University of Allahabad, Allahabad- 211002, India.

\begin{abstract}
Cancer is considered as major leading cause for death in India and around world. Modern drug-targeted therapies have undoubtedly improved treatment to the cancer patients but also evoke severe side effects. Organ failure and immunosuppression is also a reason for death of cancer patients. However, advanced metastasized stage of cancers remained untreatable at present. So, there is need for the safer and more effective treatment for the improvement of efficiency and to lower the treatment cost to treat the disease. To readdress the above mentioned issues, phytochemical (s) based therapies are being advocated. Phytomedicine is an emerging strategy for the prevention, delaying, impeding the occurrence of cancer and curing the patients. The active herbal compounds of plants induce cytoprotective enzymes by the modulation of molecular targets of cancer while acting in co-ordination to detoxify and remove reactive substances formed by carcinogenic agents. The plant based principles have been reported to possess anti-carcinogenic, anti-proliferative and anti-mutagenic properties and hence exhibit potential to induce and stimulate cell death by genotoxic damage and reduction-oxidation imbalance in cells. These herbal compounds may inhibit or reverse multi-stages of cancer proliferation. This review summarizes an updated account of research in cancer chemoprevention and treatment strategy using phytochemical agents from medicinal plants. The underlying molecular mechanisms of actions of phytochemicals, the challenges in developing phytochemicals as effective anticancer drugs and possible solutions are also illustrated.
\end{abstract}

Keywords: Cancer, phytochemicals, anti-cancer, chemoprevention, apoptosis, mechanism

\section{Introduction}

Cancer is recognised as an abnormal growth of cells. It is originated due to lack of proper regulation in cell cycle. Cancer develops through an accumulation of genetic changes or mutations which could emerge due to different factors which could be physical (such as UV and other radiations), chemical (such as chewing and smoking of tobacco, chemical pollutants/mutagens), biological (such as viruses) and in some cases it may be hereditary. The types of damages within DNA may be induced by free radicals including strand breaks (single or double strand breaks), various forms of base damage in DNA (such as 8-hydroxyguanosine, thymine glycol, damage to deoxyribose sugar as well as DNA protein cross links) result into a heritable change in the DNA (mutations) thus causing cancer in the germ cells or malformations in fetus (somatic cells). Different types of free radicals have been reported to react with the biomolecules by (i) electron donation and electron acceptance (ii) hydrogen abstraction, (iii) addition reactions, (iv) self-annihilation reactions and (v) by disproportionation [1], leading to the production of reactive oxygen species (ROS) and reactive nitrogen species (NOS) which are linked to onset of cancer and other severe diseases [2]. The consequences of free radical induced oxidative stress are presented in Figures $\mathbf{1}$ and $\mathbf{2}$.

\section{Cancers at global and Indian context}

Earlier cancers were reported only in developed countries but ow developing countries are also getting affected [3]. Acording to World Health Organization (WHO) the percentage of diagnosed cancer cases in developing countries may increase by more than $60 \%$ in 2030 [4]. Ferlay et al. (2008) have presented a 

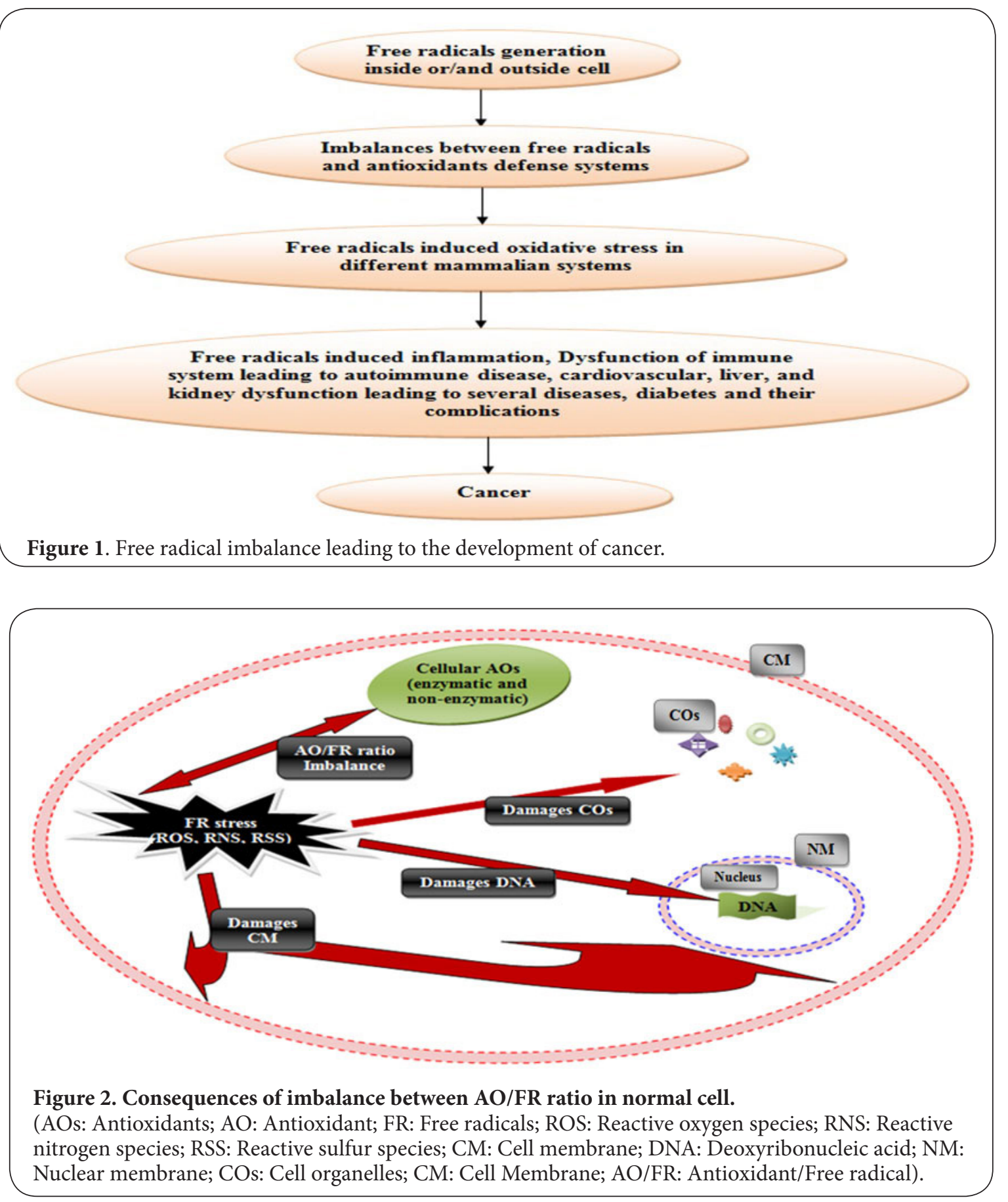

worldwide estimate of new cancer cases and cancer deaths to be about 12.7 million and 7.6 million, respectively [4]. Several workers have reported that the cancer rates in successive generations of migrants shifts in the direction of prevailing rates in host country, suggesting that the variations in cancer rates largely reflect differences in environmental risk factors such as lifestyle and culture etc. rather than their genetic differences [5]. A list of gender based common diagnosed cancers along the world has been listed in Table 1. In general, the life style have been known to be the major factors for cancer development and as an infectious agents in developing countries. While prevalence of smoking is declining in developed countries [6], it is increasing in some developing countries which may be a main cause of increase in the burden of cancer in the developing countries [7]. However, the complete effect of these unhealthy lifestyle changes on the cancer burden in developing countries are likely to take decades to be realized $[\mathbf{8}, \mathbf{9}]$. 
Gupta et al. Biochemical Compounds 2017,

http://www.hoajonline.com/journals/pdf/2052-9341-5-2.pdf

Table 1. Commonly diagnosed cancers based on gender.

\begin{tabular}{llll}
\hline \multicolumn{3}{ll}{ Gender diagnosed with different types of cancers and their corresponding countries } \\
\hline Countries & & \multicolumn{1}{l}{ different types of cancers } \\
\hline Male & Female & Male & Female \\
\hline Eastern Europe and Asia & $\begin{array}{l}\text { Australia, Western Asia, North } \\
\text { Africa, North America, and parts } \\
\text { of South America }\end{array}$ & lung cancer & breast cancer \\
& $\begin{array}{l}\text { Central America, parts of South } \\
\text { North America, Australia, }\end{array}$ & prostate cancer & cervical cancer \\
$\begin{array}{l}\text { Western and Northern Europe, } \\
\text { and South America }\end{array}$ & $\begin{array}{l}\text { America, Sub-Saharan Africa, } \\
\text { and India }\end{array}$ & & \\
$\begin{array}{l}\text { West Africa } \\
\text { central parts of Africa }\end{array}$ & $\begin{array}{l}\text { Mongolia and Vietnam } \\
\text { East Africa }\end{array}$ & liver cancer & liver cancer \\
Egypt & NA & Kaposi sarcoma & lung cancer \\
\hline
\end{tabular}

\section{Review}

Prevention and treatment for cancer by phytochemicals Prevention of a disease is always considered superior approach than its cure. A large number of medicinal herbal plants have been reported to prevent and treat various diseases for thousands of years [10]. The naturally occurring bioactive chemical components derived from plants have been reported to be exerting their beneficial effects, and have also been confirmed for their anti-cancerous activities (Table 2) [11-145]. The available experimental and epidemiological data have shown that a variety of nutritional factors including vitamin A, C, E, beta-carotene and micronutrients and different phytochemicals found in edible and non-edible plants can act as anti-cancer agents and inhibit the process of cancer development. Extensive studies on anti-cancer phytochemicals has been done by Wang et al. (2012) [10]. The name and properties of these herbal compounds are shown in Table 2.

\section{Interaction of phytochemicals with signaling pathways involved in apoptosis of cancer cells}

Many phytochemicals used as anti-inflammatory or anti-viral reagents target the apoptosis pathways in cancer [146]. Based on practical experiences of applications of traditional Chinese medicines, the involvement of apoptosis pathways was deciphered [146]. Apoptosis is the process of programmed cell death that may occur in multicellular organisms which includes blebbing, cell shrinkage, and nuclear fragmentation. The apoptosis mechanism involves several signalling pathways. Apoptotic proteins cause mitochondrial swelling and increase the permeability of the mitochondrial membrane through membrane pores and leak out the apoptotic effectors [147].

Small mitochondrial derived activators of caspases (SMACs) are released from mitochondria into cytosol. These activators bind to inhibitor of apoptosis proteins (IAPs), inactivate IAPs and prevent them from arresting the apoptotic processes. Caspases, which carry out the cell degradation and are suppressed by IAPs, proceed for cell apoptosis process [148]. Cytochrome c released from mitochondria due to the formation of mitochondrial apoptosis-induced channel
(MAC) in the outer membrane of mitochondria and binds with apoptotic protease activating factor-1 (Apaf-1) and ATP. This assembly then binds to pro-caspase- 9 followed by the formation of an apoptosome and cleaves pro-caspase and release active caspase- 9 , which is then followed by the activation of caspase-3 [149]. Bcl-2 family proteins regulate MAC and Mitochondrial Outer Membrane Permeabilization Pore (MOMPP) complex. The anti-apoptotic Bcl-2, Bcl-xL or $\mathrm{Mcl}-1$ inhibits the formation of the pore [150]. When binding of Tumor Necrosis Factor (TNF), a cytokine mainly produced by activated macrophages, with its receptor takes place, the cell survival and inflammatory responses are initiated. The interaction of FasL (a trans-membrane protein of the TNF family) and Fas receptor (Apo-1 or CD95) forms Fas-associated death domain protein (FADD), caspase-8, and caspase-10 complex, also called death-inducing signaling complex (DISC) [151]. In mammalian cells, a balance between pro-apoptotic (BAX, BID, $\mathrm{BAK}$, or $\mathrm{BAD}$ ) and anti-apoptotic (Bcl-2 and $\mathrm{Bcl}-\mathrm{XI}$ ) proteins of the $\mathrm{BCl}-2$ family is maintained. Caspase activators (such as cytochrome $c$ and SMAC) can be released from the mitochondrial membrane when the pro-apoptotic homodimers are formed in the outer-membrane of the mitochondrion. Inhibitor caspases (caspase 2, 8, 9 and10) may require certain adaptor proteins. The effector caspases (caspases 3, 7 and 6) are activated by the active initiator caspase via proteolytic cleavage and degradation of intracellular proteins to promote the cell death process. Some of the cancer and phytochemicals associated apoptotic signalling mechanisms are discussed in more detail in the following sections.

\section{Cyclooxygenases-2 (COX-2)}

Cyclooxygenases are bi-functional membrane-bound enzymes $[152,153]$. Housekeeping function mediated by COX-1 and COX-2 is low in most cells but is constitutively elevated in colorectal and other cancers [152]. COX-2 has been reported to be associated in colorectal cancers with larger tumour size and poor survival of the cells [154] therefore the expression of COX-2 has been proposed to be a nutritional target for colon cancer [155]. COX-2 may be induced at very early 
Gupta et al. Biochemical Compounds 2017,

http://www.hoajonline.com/journals/pdf/2052-9341-5-2.pdf

Table 2. Phytochemicals from medicinal plants, their sources and anticancer functions against cancers.

\begin{tabular}{|c|c|c|c|c|c|}
\hline S. No. & $\begin{array}{l}\text { Naturally } \\
\text { occurring } \\
\text { compound }\end{array}$ & Source Plant & Preventive / protective functions & Organ & References \\
\hline 1 & Apigenin & $\begin{array}{l}\text { Moringa peregrina } \\
\text { Celery, Chamomile } \\
\text { Parsley }\end{array}$ & $\begin{array}{l}\text { Induced apoptosis through different signalling } \\
\text { pathways i.e. leptin/leptin receptor pathway or by } \\
\text { activating p38 MAPK pathway }\end{array}$ & $\begin{array}{l}\text { Breast cancer cell lines, } \\
\text { colon cancer cell line, } \\
\text { lung adenocarcinoma } \\
\text { cell line and B16 cells. }\end{array}$ & [11-17] \\
\hline 2 & Berbamine & Berberine amarensis & Apoptosis dependent on Caspase-3 & NA & {$[18-20]$} \\
\hline 4 & Betulinic acid & Betula alba & Through mitochondrial apoptotic pathway & NA & {$[25-28]$} \\
\hline 5 & Colchicine & $\begin{array}{l}\text { Colchicum } \\
\text { autumnale }\end{array}$ & Anti-mitotic & NA & {$[29,30]$} \\
\hline 6 & $\begin{array}{l}\text { Curcumin } \\
\text { (diferuloylmeth- } \\
\text { ane) }\end{array}$ & Curcuma longa & 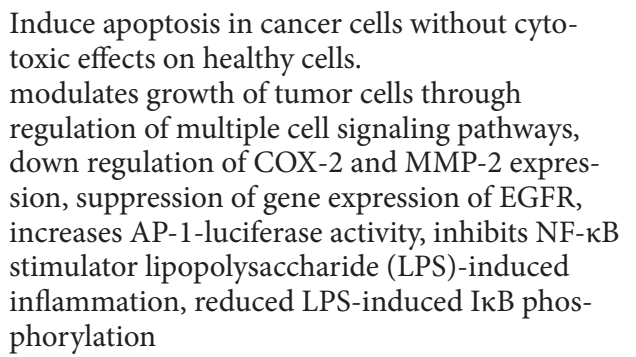 & $\begin{array}{l}\text { Colon cancer, breast } \\
\text { cancer, lung metastases, } \\
\text { and brain tumor, } \\
\text { human prostate cancer } \\
\text { PC- } 3 \text { cells }\end{array}$ & [31-37] \\
\hline 7 & Crocetin & $\begin{array}{l}\text { Crocus sativus } \\
\text { (Saffron) }\end{array}$ & $\begin{array}{l}\text { Exact mechanism of action is still not clear but it } \\
\text { may be due to the inhibition of nucleic acid syn- } \\
\text { thesis, enhancing anti-oxidative system, inducing } \\
\text { apoptosis and hindering growth factor signaling } \\
\text { pathways. }\end{array}$ & $\begin{array}{l}\text { Hepatocellular carcino- } \\
\text { ma, human lung cancer, } \\
\text { pancreatic cancer cell } \\
\text { line, skin carcinoma, } \\
\text { colorectal cancer cells, } \\
\text { and breast cancer. }\end{array}$ & {$[38-45]$} \\
\hline 8 & Cyanidin & $\begin{array}{l}\text { Berries, plums, red } \\
\text { cabbage and red onion. }\end{array}$ & $\begin{array}{l}\text { Inhibiting cell proliferation, Inhibiting iNOS } \\
\text { and COX-2 gene expression, blocks activation of } \\
\text { ErbB } 2 / \mathrm{cSrc} / \mathrm{FAK} \text { pathway, induce the activation } \\
\text { of AP- } 1 \text { and NF- } \mathrm{kB} \text {, blocked the activation of the } \\
\text { Fyn kinase signaling pathway }\end{array}$ & $\begin{array}{l}\text { Colon cancer cells, } \\
\text { breast cancer cells, } \\
\text { Oesophagus cell line, } \\
\text { tumorigenic rat } \\
\text { esophagus cell line, } \\
\text { epidermal skin cell line }\end{array}$ & {$[46-50]$} \\
\hline 11 & Ellipticine & Ochrosia borbonica & Inhibition of DNA topoisomerase II & NA & {$[59]$} \\
\hline 12 & $\begin{array}{l}\text { Epigallocatechin } \\
\text { gallate (EGCG) }\end{array}$ & Green tea & $\begin{array}{l}\text { Inhibits anti-apoptotic protein Bcl-xl, interfered } \\
\text { with EGFR signaling, inhibited hepatocyte } \\
\text { growth factor-induced cell proliferation, caused } \\
\text { damage to mitochondria and JNK mediated } \\
\text { EGCG-induced apoptotic cell death mediated } \\
\text { by Nrf2 }\end{array}$ & $\begin{array}{l}\text { Brain, prostate, cervical, } \\
\text { bladder cancers, colonic } \\
\text { premalignant lesions } \\
\text { in mice, human colon } \\
\text { cancer cells }\end{array}$ & {$[60-66]$} \\
\hline 13 & Etoposide & $\begin{array}{l}\text { Podophyllum } \\
\text { peltatum }\end{array}$ & Mitotic block & NA & {$[67]$} \\
\hline 14 & Fisetin & $\begin{array}{l}\text { Acacia greggii, Acacia } \\
\text { berlandieri, (Strawber- } \\
\text { ry and apple Euroasian } \\
\text { smoketree, persim- } \\
\text { mon, grape, onion, and } \\
\text { cucumber) }\end{array}$ & $\begin{array}{l}\text { Induced the expression of Nrf } 2 \text { and the phase } \\
\text { II gene product HO- } 1 \text {, Inhibits PI } 3 \text { K/Akt and } \\
\text { mTOR signaling, and Wnt signaling through } \\
\text { the modulation of beta-catenin. Decreased cell } \\
\text { viability with G1-phase arrest and disrupted } \\
\text { Wnt/ } \beta \text { - catenin signaling, inhibits the abilities of } \\
\text { adhesion, migration, and invasion, and decreases } \\
\text { the nuclear levels of NF- } \kappa \mathrm{B} \text { and AP-1 }\end{array}$ & $\begin{array}{l}\text { Human colon cancer } \\
\text { cells, human lung } \\
\text { cancer cells, human } \\
\text { retinal pigment } \\
\text { epithelial cells }\end{array}$ & {$[68-74]$} \\
\hline
\end{tabular}


Gupta et al. Biochemical Compounds 2017,

Continuation of Table 2.

\begin{tabular}{|c|c|c|c|c|c|}
\hline S. No. & $\begin{array}{l}\text { Naturally occurring } \\
\text { compound }\end{array}$ & ig Source Plant & Preventive / protective functions & Organ & References \\
\hline 15 & Flavopiridol & Amoora rohituka & Inhibition of cell cycle progression & NA & {$[75]$} \\
\hline 16 & Genistein & $\begin{array}{l}\text { Vicia faba } \\
\text { Soyabeans (kudzu, } \\
\text { psoralea) Flemingia } \\
\text { vestita (coffee) }\end{array}$ & $\begin{array}{l}\text { Inhibition of 3A 4-mediated metabolism and } \\
\text { oxidative metabolism } \\
\text { antiangiogenic effects and inhibiting the growth } \\
\text { factors, inhibiting DNA topoisomerase II. }\end{array}$ & Leukemia, colon cancer & {$[76-82]$} \\
\hline 18 & Harringtonine & $\begin{array}{l}\text { Cephalotaxus } \\
\text { harrintonia }\end{array}$ & Inhibition of protein synthesis & NA & {$[87]$} \\
\hline 19 & 4-Ipomeanol & Ipomea batatas & $\begin{array}{l}\text { Through cytochrome P } 450 \text { mediated conversion } \\
\text { into DNA binding metabolites }\end{array}$ & NA & {$[88]$} \\
\hline 21 & Lycopene & $\begin{array}{l}\text { Tomato, red carrot, } \\
\text { watermelon, and red } \\
\text { papaya }\end{array}$ & $\begin{array}{l}\text { By activating phase II detoxification enzymes, } \\
\text { Inhibits human cancer cell proliferation, and } \\
\text { suppress insulin-like growth factor-I stimulated } \\
\text { growth }\end{array}$ & $\begin{array}{l}\text { Prostate cancer } \\
\text { breast cancer cells } \\
\text { endometrial cancer cells } \\
\text { and colon cancer cells }\end{array}$ & [96-100] \\
\hline 22 & Pervilleines & Erythroxylum pervillei & As a P-glycoprotein inhibitor & NA & {$[101,102]$} \\
\hline 23 & $\begin{array}{l}\text { Phenyl } \\
\text { isothiocyanates } \\
\text { (PEITC) }\end{array}$ & $\begin{array}{l}\text { Broccoli, cabbage } \\
\text { (cruciferous } \\
\text { vegetable) }\end{array}$ & $\begin{array}{l}\text { Induced the activation of caspase- } 8,-9 \text {, and } \\
\text {-3-dependent pathways, leading to cell cycle } \\
\text { arrest at the G2/M phase by modulation of } \\
\text { cyclin B1 expression, caspase-independent } \\
\text { down regulation of Mcl-1, Akt inactivation } \\
\text { and activation of JNK, also increase the death } \\
\text { receptors (DR } 4 \text { and DR5) expression, induced } \\
\text { caspase- } 8 \text { and truncated BID, down-regulated } \\
\text { the ERK } 1 / 2 \text { and MEK phosphorylation. }\end{array}$ & $\begin{array}{l}\text { Breast cancer cells, } \\
\text { cervical cancer, } \\
\text { osteogenic sarcoma, } \\
\text { prostate cancer, } \\
\text { myeloma cell lines and } \\
\text { metastatic human lung } \\
\text { cancer cells. }\end{array}$ & [103-114] \\
\hline 25 & Resveratrol & $\begin{array}{l}\text { Grapes skin and } \\
\text { peanuts }\end{array}$ & 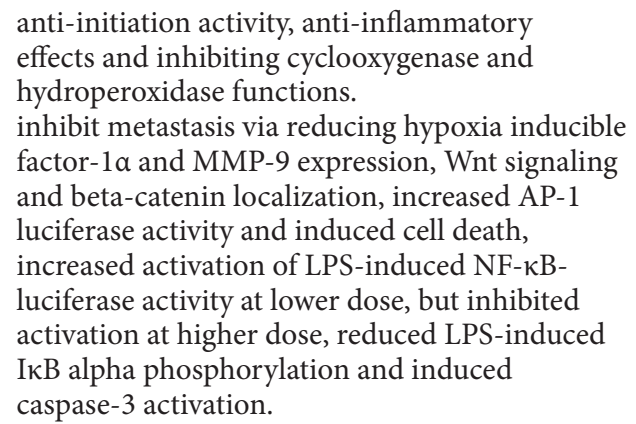 & $\begin{array}{l}\text { human promyelocytic } \\
\text { leukemia, skin tumor, } \\
\text { gastrointestinal tract } \\
\text { tumor, colon cancer } \\
\text { cell, human colon } \\
\text { cancer cell line }\end{array}$ & [116-120] \\
\hline
\end{tabular}


Gupta et al. Biochemical Compounds 2017,

http://www.hoajonline.com/journals/pdf/2052-9341-5-2.pdf

doi: $10.7243 / 2052-9341-5-2$

\section{Continuation of Table 2.}

\begin{tabular}{|c|c|c|c|c|c|}
\hline S. No. & $\begin{array}{l}\text { Naturally occurrin } \\
\text { compound }\end{array}$ & ng Source Plant & Preventive / protective functions & Organ & References \\
\hline 26 & Rosmarinic acid & $\begin{array}{l}\text { Culinary spice and me- } \\
\text { dicinal herbs (lemon } \\
\text { balm, peppermint, } \\
\text { sage, thyme, oregano, } \\
\text { and rosemary) }\end{array}$ & $\begin{array}{l}\text { inhibits migration, adhesion, and invasion via } \\
\text { the NF- } \kappa \mathrm{B} \text { pathway and simultes suppression of } \\
\text { interleukin- } 8 \text { (IL-8), sensitized TNF- } \alpha \text { - induced } \\
\text { apoptosis through the suppression of NF- } \kappa B \\
\text { and reactive oxygen species (ROS) and sup- } \\
\text { pressed NF- } \kappa \mathrm{B} \text { activation through inhibition of } \\
\text { phosphorylation and degradation of I } \mathrm{B} \alpha \text {, also } \\
\text { reduced } 12-\mathrm{O}-\text {-tetradecanoylphorbol-13-acetate } \\
\text { (TPA)-induced COX-2 promoter activity and } \\
\text { protein levels, repressed binding of the AP-1 }\end{array}$ & $\begin{array}{l}\text { human colon carcinoma } \\
\text { cells, breast carcinoma, } \\
\text { human leukemia cells, } \\
\text { non-malignant breast } \\
\text { epithelial cell line }\end{array}$ & [121-124] \\
\hline 27 & Salvicine & Salvia priontis & Inhibits topoisomerase II & NA & {$[125]$} \\
\hline 28 & Silvestrol & Aglaia foveolata & $\begin{array}{l}\text { Triggers extrinsic pathway of programmed cell } \\
\text { death of tumor cells through mitochondrial }\end{array}$ & NA & {$[126]$} \\
\hline
\end{tabular}

29 Sulforaphane cruciferous vegetables (broccoli, Brussels sprouts and cabbages)

$\begin{array}{lll}30 & \text { Topotecan } & \begin{array}{l}\text { Comptotheca } \\ \text { acuminate }\end{array} \\ 31 \quad \text { Triterpenoids } & \begin{array}{l}\text { wax-like coatings of } \\ \text { fruits and medicinal } \\ \text { herbs }\end{array}\end{array}$

32 Vitamin D3 Mushroom

33 Vitamin E Sunflower oil

$\begin{array}{lll}34 & \text { Vindesine } & \text { Vinca roseus } \\ 35 & \text { Vinorelbine } & \text { Vinca roseus }\end{array}$

inhibit NF- $\kappa$ B, STAT3 and COX-2, inhibit AKT and ERK activation and suppress cell proliferation by suppressing the ErbB2 pathway, selectively inhibit the HMG-CoA reductase pathway through posttranslational degradation, suppress the activity of NF- $\kappa \mathrm{B}$, reduced the activation of ERK MAP kinase and that of its downstream mediator ribosomal protein S6 kinase (RSK) and suppressing the activation of AKT.

Mitotic block

Mitotic block breast cancer stem cells, colon cancer cells, human hepatoma cells, human prostate cancer cells, liver and skin tumorigenesis in mice [127-132] Enhanced apoptosis, stimulating DR4, DR5, PARP cleavage, suppressing COX-2, IL- $1 \beta$, NF$\kappa \mathrm{B}, \mathrm{IKK} \alpha / \beta$, cyclins (D1, A, B1), ER $\alpha$ protein and mRNA, HER2 phosphorylation, caveolin-1, Akt, and blocking cell cycle at G1, G1-S, G2-M. Vitamin D receptors (VDR). pancreatic cancer
NA

breast cancer, pancreatic cancer

breast cancer, colon cancer, ovarian cancer, prostate cancer and

Anti-proliferative, proapoptotic pancreatic cancer cell lines,

[140-143]

NA

NA 
stage of cancer development therefore the prevention of its aberrant expression may prevent the formation of cancer [156]. COX-2 contained a number of upstream regulatory sequences specific for binding with a variety of transcription factors, such as NF-KB, SP-1 transcription factor and activator protein-1 (AP-1) [157]. These transcription factors could be the final executors for a number of intracellular signaling pathways which make the COX-2 transcriptional regulation highly complicated.

\section{Hedgehog signaling pathway (HSP)}

Hedgehog signaling pathway (HSP) has been reported to be involved in providing the instructions to the cells for their proper development. The abnormal activation of this pathway may give rise to cancer through transformation of adult stem cells into cancer stem cells. Therefore, the researchers are looking for specific inhibitors of this pathway to devise an efficient cancer therapy [158]. In vertebrates, when sonic hedgehog (SHH) binds to the Patched-1 (PTCH1) receptor, the downstream protein Smoothened (SMO) which is inhibited by PTCH1, resulting in SHH activation leading to the activation of GLI transcription factors [159]. The accumulation of activated $\mathrm{GLI}$ in the nucleus controls the transcription of hedgehog target genes. Therefore the activation of hedgehog signaling pathway results into the increases of angiogenic factors and the decreases of apoptotic genes $[160,161]$. Hedgehog signaling pathway has been extensively reviewed as a target pathway for cancer treatment [162]. Therefore the approaches to regulate the hedgehog signaling pathway have been used to inhibit cell growth and promote apoptosis in prostate cancer by modulating SMO, PTCH and Gli3 (5E1) [163].

\section{NF-kB pathway}

NF-KB is a family of rapid-acting primary transcription factors. They are present in inactive state inside cells and do not require new protein synthesis to get activated which allows them to be the first responder to harmful stimuli. Free radicals such as reactive oxygen species (ROS), lipopolysaccharide (LPS), TNF alpha and IL-1 beta are some examples of NF-KB inducers. The NF-KB dimmers are sequestered in the cytoplasm by a family of IKBs. The ankyrin repeat domains of IKBs mask the nuclear localization signals (NLS) of NF-KB. IKBs are modified by ubiquitination via IKB kinases (IKK). NF-KB is then free to enter in to the nucleus where it may turn on the expression of specific genes. The NF-KB turns on expression of its own repressor, IKB alpha, which in turn reinhibits NF$K B$, which results in oscillating levels of NF-KB activity [164]. Blocking NF-KB may cause tumor cells to stop proliferating, become more sensitive to the action of anti-cancer agents and to die [165].

\section{Nrf2 pathway}

Nuclear factor (erythroid-derived 2)-like 2 (Nrf2, or NFE2L2) is a transcription factor that regulates antioxidant responses
[166]. Nrf2 is a basic leucine zipper (bZIP) transcription factor and under normal condition, Nrf2 is tethered in the cytoplasm by the Kelch like-ECH-associated protein 1 (Keap1) [167]. Oxidative stress disrupts critical cysteine residues in Keap1 and releases Nrf2 to be translocated into the nucleus. There, Nrf2 heterodimerizes with small Maf proteins binds to the anti-oxidant response element (ARE) in the promoter region of many antioxidative genes and initiate their transcription [168]. The cytoprotective proteins include phase II drug metabolizing enzymes such as glutathione-S-transferase (GST), NAD(P)H-quinone oxidoreductase-1 (NQO1), heme oxygenase-1 (HO-1), UDP-glucuronosyl transferase (UGT) or phase III transporters (multidrug resistance-associated proteins (MRPs) [169-173]. Mechanism of Nrf2 pathway is summarised in Figure 3.

\section{PI3K pathway}

Phosphatidylinositol 3-kinases (PI3Ks) are a family of enzymes involved in cell growth, proliferation, differentiation, survival and intracellular trafficking. Activated $\mathrm{PI} 3 \mathrm{~K}$ produces Phosphatidylinositol $(3,4,5)$-trisphosphate $(\operatorname{Ptd} \operatorname{lns}(3,4,5) \mathrm{P} 3)$ and Phosphatidylinositol $(3,4,5)$-disphosphate (Ptdlns(3,4)P2). The translocation of AKT across the plasma membrane are restricted due to that of the Ptdlns $(3,4,5) \mathrm{P} 3$ and Ptdlns $(3,4)$ $\mathrm{P} 2$. The activity of PI3K may significantly contribute to the cellular transformation and the development of cancer. Inhibition of PI3K could be an important therapeutic strategy for suppressing cancer development [174].

\section{STAT 3 pathway}

STAT 3 (Signal transducer and activator of transcription 3) is a transcription factor that plays a key role in cell growth and apoptosis. STAT3 is activated through phosphorylation of tyrosine 705 and serine 727 residues in response to cytokines and growth factors then form homo- or heterodimers that translocate to the cell nucleus. The constitutive STAT3 activation has been associated with poor prognosis, anti-apoptotic and proliferative effects in cancer cells [175].

\section{Wnt pathway}

Wnt proteins are involved in normal physiological process of adult animals as well as in embryogenesis and cancers [176]. These proteins activate various pathways in the cell including canonical and noncanonical Wnt pathways and exert their effect in cell differentiation, embryonic development and generation of cell polarity [177]. In canonical pathway, the Wnt proteins bind to cell-surface receptors, causing the activation Dishevelled (DSH) family proteins and ultimately change in the amount of $\beta$-catenin that reaches into the nucleus. DSH complex inhibits axin, GSK-3 and APC complex proteins which normally promotes the proteolytic degradation of $\beta$-catenin. The inhibition of $\beta$-catenin destruction allows cytoplasmic $\beta$-catenin stabilization and entering the nucleus to interact with TCF/LEF family transcription factors to promote specific 


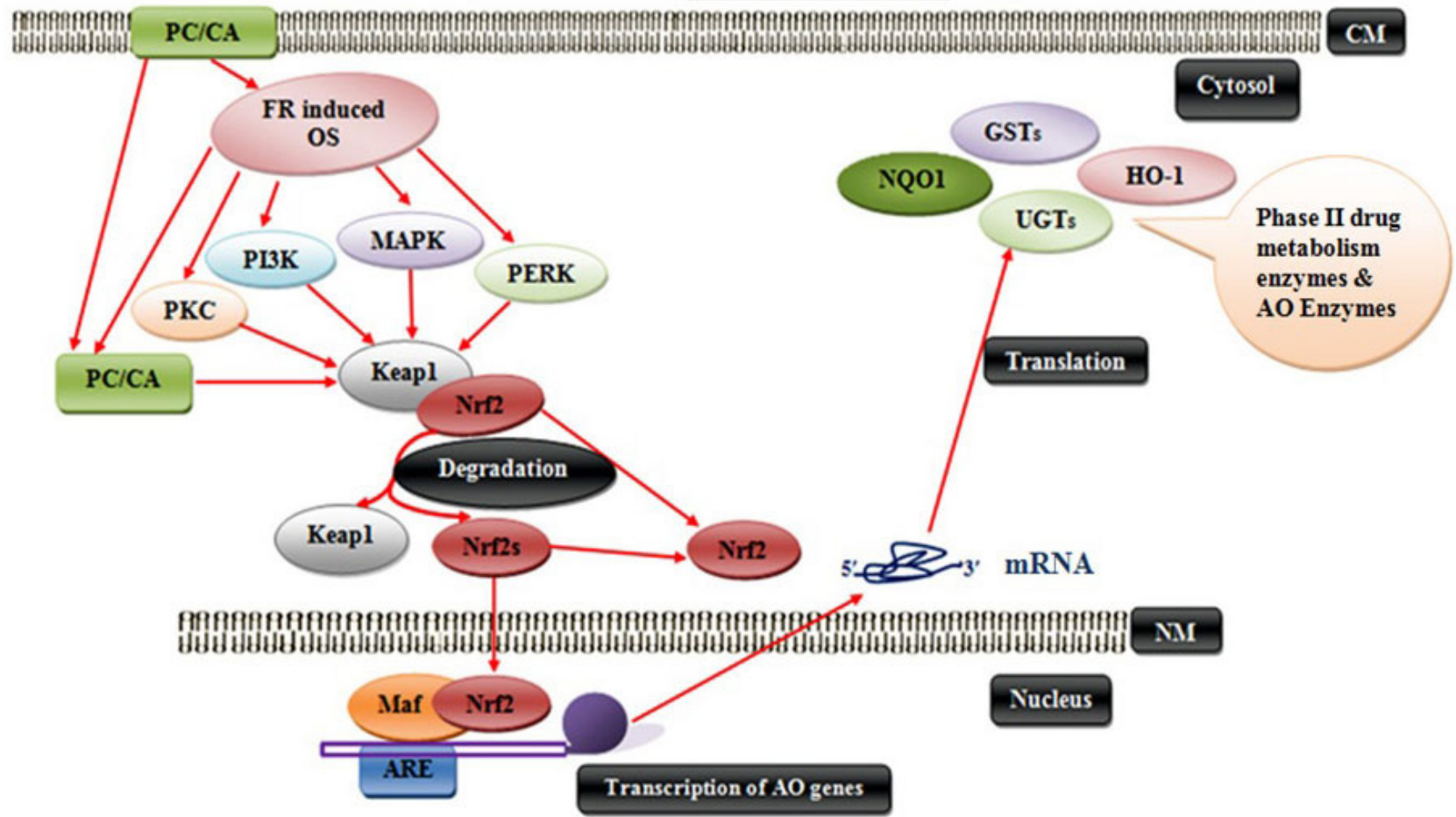

Figure 3. Mechanism for the regulation of Nrf2 mediated antioxidant gene expression by PC.

Nrf2 remains associated with Keap1 protein in the form of the Keap1-Nrf2 complex under homeostatic condition, hence retained inside the cytoplasm by Keap1 protein. Interaction of PCs with Keap1 protein triggers the release of Nrf2 from the Keap1-Nrf2 complex. CA generated FR may activate the various signaling pathways, which may triggers the release and translocation of Nrf2 from cytosol to nucleus, which is responsible for the expression of AO genes. (PC- Phytochemical; CA-Chemopreventive agent; OS- Oxidative stress; FR-Free radical; PKC- Protein kinase C; PI3K- phosphoinositide 3-kinase; MAPK- mitogen-activated protein kinase; Keap1- Kelch like-ECH-associated protein 1; Nrf2- nuclear factor-erythroid 2-related factor 2; ARE- antioxidant response element; AO- Antioxidative; mRNA- Messenger ribonucleic acid; UGT- UDP glucuronosyltransferase; HO-1-

hemeoxygenase-1; GST- glutathione S-transferase; NQO1- NAD(P)H-quinone oxidoreductase 1; CM- Cellular membrane; NMNuclear membrane).

expression of a gene. Therefore, the modifications in Wnt APC, axin, and TCF are associated with carcinogenesis. The non-steroidal anti-inflammatory drugs (NSAIDs) that interfere with $\beta$-catenin signaling have been shown to prevent colorectal cancer [178].

Besides the mechanisms listed above, there are several other mechanisms for apoptosis such as the extra-virgin olive oil may target the human epidermal growth factor receptor (HER2) in breast cancer [179], resveratrol may reduce hypoxia-induced factor-1a, MMP-9 expression in colon cancer, lycopene may alter mevalonate pathway and many others [180].

Pharmaceutical challenges and opportunities in developing phytochemicals based drugs in therapy for cancer Many natural dietary phytochemicals have been studied for cancer prevention and treatment. These native phytocompounds and/or their synthetic analogues have guided continuing research to bring them into the market as anti- cancer agents. Applying phytochemicals to cancer patients for chemoprevention encounters an immediate challenge in terms of their effects on human, as it is not feasible to design a clinical study to prove that the suppression of cancers in patient is due to the intake of phytochemicals. Though the chemical structures of some of the potential phytochemicals are well understood, but their physicochemical properties are not well documented yet and needs detailed investigation. Bioavailability of phytochemicals is another challenge that needs to be addressed. The nanotechnology, liposomes, micelles and phospholipids complexes have been applied to increase the water solubility of phytochemicals to enhance their bioavailability. Phytochemicals are generally considered as non-toxic materials but they may exert their toxicities to animals or humans at certain situation (drug-drug interaction and concentration), which may delay their application in the clinical studies and application in cancer treatment. This may be due to the synergistic effects existing in natural 
compounds consumed as a whole rather than a single extracted/ purified compound. Using recently developed new technologies; some novel natural plant based compounds may be identified and developed as anticancer agents for chemopevention of the disease. Such phytochemicals may prove to be cost effective, safe and more potential with enhanced efficacy against cancer [181]. However, a thorough study of these phytocompounds and their pharmacological effects may generate insights for their drugability as well as transition from laboratory to the patients.

\section{Conclusion}

Phytochemicals in cancer chemoprevention are considered as the cheapest option in cancer treatment. Phytochemicals have been widely used in preclinical cancer prevention and treatment studies. Phytochemical chemopreventive agents are believed to play significant roles in controlling, inhibiting, and blocking signals which can cause translation of normal cells to cancer cells. The chemoprevention of cancer using phytochemicals have been such an attractive approach therefore efforts should be made to thoroughly understand their potencies, pharmacokinetics, pharmacodynamic responses, metabolisms, toxicities, drug-drug interactions, polymorphisms, formulations dose and to explore the molecular mechanisms of phytochemicals in cancer treatment more clearly. Genomic instability provides a means for selective targeting of cancer cells over normal cells. Among the various cancers chemopreventive agents many cause changes in chromatin conformation, disrupt the intracellular redox balance and deregulate DNA repair proteins. Thus, these compounds might activate the DNA damage response in cancer cells as compared to the normal cells. It is hoped that the improved understanding of these mechanisms will provide a more rational basis for combining specific dietary compounds and radiation therapy or chemotherapy approaches. More studies should be focused on dose-dependent responses and toxicity of the phytochemicals to ascertain their safety before usage.

\section{List of abbreviations}

ADM: antioxidant defense mechanisms

AO/FR: Antioxidant/Free radical

AO: antioxidant

AP-1: Activator protein-1

Apaf-1: Apoptotic protease activating factor-1

ARE: Anti-oxidant response element

ATP: Adenosine triphosphate

bZIP: basic leucine zipper

CA:Chemopreventive agent

CHD: Chromodomain helicase

DNA-binding protein

CM: Cell membrane; Cellular membrane

COs: Cell organelles

COX-2: Cyclooxygenases-2

CpG :"-C—phosphate-G-"
CYP enzymes:

DDR : DNA damage response

DISC: death-inducing signaling complex

DME: drug metabolism enzymes

DNA: Deoxyribonucleic acid

DSH: Dishevelled

EGCG: gastrointestinal toxicities (green tea polyphenols)

FADD : Fas-associated death domain protein

FR: Free radicals

GST: glutathione S-transferase

HER2: human epidermal growth factor receptor

HO-1: hemeoxygenase-1

IAPs: inhibitor of apoptosis proteins

ICMR: Indian Council of Medical Research

IKK: IKB kinases

IL: Interleukin

INO80: inositol requiring 80

Keap1: Kelch like-ECH-associated protein 1

LPS: lipopolysaccharide

MAC: mitochondrial apoptosis-induced channel

MAPK: Mitogen-activated protein kinase

MBDs: Methyl-CpG-binding domain proteins

MOMPP: Mitochondrial Outer Membrane Permeabilization Pore

mRNA: Messenger ribonucleic acid

MRPs: Multidrug resistance-associated proteins

mTOR: Mechanistic target of rapamycin

NAD: Nicotinamide dinucleotide

NF-kB: Nuclear factor kappa B

NM: Nuclear membrane

NQO1: NAD(P)H-quinone oxidoreductase 1

Nrf2 or NFE2L2: Nuclear factor-erythroid 2-related factor 2

NSAIDs: Non-steroidal anti-inflammatory drugs

OS: Oxidative stress

PARP: poly(ADP-ribose) polymerase

PC: Phytochemical

PI3K: phosphoinositide 3-kinase

PKC: Protein kinase $C$

Plk1: Polo-like kinase 1

PTCH: Patched receptor

PTCH1: Patched-1 receptor

Ptdlns(3,4)P2): Phosphatidylinositol (3,4,5)-disphosphate

Ptdlns(3,4,5)P3): Phosphatidylinositol (3,4,5)-trisphosphate

RNAs: Ribonucleic acids

RNS: Reactive nitrogen species

ROS: Reactive oxygen species

RSS: Reactive sulfur species

$\mathrm{SHH}$ : Sonic hedgehog

SMACs: Small mitochondrial derived activators of caspases

STAT3: Signal transducer and activator of transcription 3

TNF alpha: Tumour Necrosis Factor

UV: ultra violet

WHO: world health organization

\section{Competing interests}

The authors declare that they have no competing interests. 
Gupta et al. Biochemical Compounds 2017,

http://www.hoajonline.com/journals/pdf/2052-9341-5-2.pdf

doi: $10.7243 / 2052-9341-5-2$

\section{Authors' contributions}

\begin{tabular}{|l|c|c|c|}
\hline Authors' contributions & VKG & RS & BS \\
\hline Research concept and design & $\checkmark$ & $\checkmark$ & $\checkmark$ \\
\hline Collection and/or assembly of data & $\checkmark$ & $\checkmark$ & $\checkmark$ \\
\hline Data analysis and interpretation & $\checkmark$ & $\checkmark$ & $\checkmark$ \\
\hline Writing the article & $\checkmark$ & $\checkmark$ & $\checkmark$ \\
\hline Critical revision of the article & $\checkmark$ & $\checkmark$ & $\checkmark$ \\
\hline Final approval of article & $\checkmark$ & $\checkmark$ & $\checkmark$ \\
\hline Statistical analysis & $\checkmark$ & $\checkmark$ & $\checkmark$ \\
\hline
\end{tabular}

\section{Acknowledgement}

First author (VKG) is grateful to the University Grant Commission (UGC), New Delhi for providing research scholarship. Second author (RS) gratefully acknowledged the Department of Science and Technology (DST-SERB) for financial assistance in the form of DST-SERB National Post-Doctoral Fellowship.

\section{Publication history}

Editors: Manicka V. Vadhanam, University of Louisville, USA. Sundeep Jaglan, CSIR-Indian Institute of Integrative Medicine, India.

Received: 07-Nov-2016 Final Revised: 07-Feb-2017

Accepted: 28-Feb-2017 Published: 10-Mar-2017

\section{References}

1. Cuzzocrea S, Riley DP, Caputi AP and Salvemini D. Antioxidant therapy: a new pharmacological approach in shock, inflammation, and ischemia/reperfusion injury. Pharmacol Rev. 2001; 53:135-59. | PubMed

2. Wichi HP. Enhanced tumour development by butylated hydroxyanisole (B HA) from the prospective of effect on fore stomach and oesophageal squamous epithelium. Food Chem Toxicol. 1998; 26:717-23.

3. American Cancer Society. Global cancer facts \& figures 2007. Atlanta (GA): American Cancer Society; 2007.

4. Ferlay J, Shin HR, Bray F, Forman D, Mathers C and Parkin DM. Cancer incidence and mortality worldwide: IARC Cancer Base No. 10. Lyon (France): IARC. 2010. | Website

5. Kolonel L and Wilkens L. Migrant studies. in: Schottenfeld D, Fraumeni JF Jr., editors. Cancer epidemiology and prevention. Oxford University Press. 3rd ed: 2006; 189-201.

6. Moller H, Fairley L, Coupland V, Okello C, Green M, Forman D, Moller $B$ and Bray $F$. The future burden of cancer in England: incidence and numbers of new patients in 2020. Br J Cancer. 2007; 96:1484-8. | Article | PubMed Abstract | PubMed FullText

7. Thun MJ, DeLancey JO, Center MM, Jemal A and Ward EM. The global burden of cancer: priorities for prevention. Carcinogenesis. 2010; 31:100-10. | Article | PubMed Abstract | PubMed FullText

8. World Health Organization. World cancer report 2008. Lyon (France): IARC. 2008.

9. Center MM, Jemal A, Smith RA and Ward E. Worldwide variations in colorectal cancer. CA Cancer J Clin. 2009; 59:366-78. | Article | PubMed

10. Wang H, Khor TO, Shu L, Su ZY, Fuentes F, Lee JH and Kong AN. Plants vs. cancer: a review on natural phytochemicals in preventing and treating cancers and their druggability. Anticancer Agents Med Chem. 2012; 12:1281-305. | Article | PubMed Abstract | PubMed FullText

11. Hoensch HP and Oertel R. Emerging role of bioflavonoids in gastroenterology: Especially their effects on intestinal neoplasia. World J Gastrointest Oncol. 2011; 3:71-4. | Article | PubMed Abstract | PubMed FullText

12. El-Alfy TS, Ezzat SM, Hegazy AK, Amer AM and Kamel GM. Isolation of biologically active constituents from Moringa peregrina (Forssk.) Fiori. (family: Moringaceae) growing in Egypt. Pharmacogn Mag. 2011;

\section{7:109-15. | Article | PubMed Abstract | PubMed FullText}

13. Turktekin $\mathrm{M}$, Konac $\mathrm{E}$, Onen $\mathrm{HI}$, Alp E, Yilmaz A and Menevse S Evaluation of the effects of the flavonoid apigenin on apoptotic pathway gene expression on the colon cancer cell line (HT29). J Med Food. 2011; 14:1107-17. | Article | PubMed

14. Leonardi T, Vanamala J, Taddeo SS, Davidson LA, Murphy ME, Patil BS, Wang N, Carroll RJ, Chapkin RS, Lupton JR and Turner ND. Apigenin and naringenin suppress colon carcinogenesis through the aberrant crypt stage in azoxymethane-treated rats. Exp Biol Med (Maywood). 2010; 235:710-7. | Article | PubMed Abstract | PubMed FullText

15. Ye Y, Wang H, Chu JH, Chou GX and Yu ZL. Activation of p38 MAPK pathway contributes to the melanogenic property of apigenin in B16 cells. Exp Dermatol. 2011; 20:755-7. | Article | PubMed

16. Clere N, Faure S, Martinez MC and Andriantsitohaina R. Anticancer properties of flavonoids: roles in various stages of carcinogenesis. Cardiovasc Hematol Agents Med Chem. 2011; 9:62-77. | Article | PubMed

17. Bruno A, Siena L, Gerbino S, Ferraro M, Chanez P, Giammanco M, Gjomarkaj $M$ and Pace E. Apigenin affects leptin/leptin receptor pathway and induces cell apoptosis in lung adenocarcinoma cell line. Eur J Cancer. 2011; 47:2042-51. | Article | PubMed

18. Wang GY, Lv QH, Dong Q, Xu RZ and Dong QH. Berbamine induces Fas-mediated apoptosis in human hepatocellular carcinoma HepG2 cells and inhibits its tumor growth in nude mice. J Asian Nat Prod Res. 2009; 11:219-28. | Article | PubMed

19. Wang GY, Zhang JW, Lu QH, Xu RZ and Dong QH. Berbamine induces apoptosis in human hepatoma cell line SMMC7721 by loss in mitochondrial transmembrane potential and caspase activation. $J$ Zhejiang Univ Sci B. 2007; 8:248-55. | Article | PubMed Abstract | PubMed FullText

20. Liang Y, Qiu X, Xu RZ and Zhao XY. Berbamine inhibits proliferation and induces apoptosis of KU812 cells by increasing Smad3 activity. J Zhejiang Univ Sci B. 2011; 12:568-74. | Article | PubMed Abstract | PubMed FullText

21. Woo HJ, Park KY, Rhu CH, Lee WH, Choi BT, Kim GY, Park YM and Choi $\mathrm{YH}$. Beta-lapachone, a quinone isolated from Tabebuia avellanedae, induces apoptosis in HepG2 hepatoma cell line through induction of Bax and activation of caspase. J Med Food. 2006; 9:161-8. | Article | PubMed

22. Krishnan P and Bastow KF. Novel mechanisms of DNA topoisomerase II inhibition by pyranonaphthoquinone derivatives-eleutherin, alpha lapachone, and beta lapachone. Biochem Pharmacol. 2000; 60:136779. | Article | PubMed

23. Frydman B, Marton LJ, Sun JS, Neder K, Witiak DT, Liu AA, Wang HM, Mao Y, Wu HY, Sanders MM and Liu LF. Induction of DNA topoisomerase II-mediated DNA cleavage by beta-lapachone and related naphthoquinones. Cancer Res. 1997; 57:620-7. | Article | PubMed

24. Li CJ, Averboukh L and Pardee AB. beta-Lapachone, a novel DNA topoisomerase I inhibitor with a mode of action different from camptothecin. J Biol Chem. 1993; 268:22463-8. I Article I PubMed

25. Liviu H, Floricuta R, Diana C, Alina T and Carmen S. Evaluation of betulin and betulinic acid content in birch bark from different forestry areas of western Carpathians. Not Bot Horti Agrob. 2012; 40:99-105.

26. Fulda $S$ and Debatin KM. Sensitization for anticancer drug-induced apoptosis by betulinic Acid. Neoplasia. 2005; 7:162-70. | Article | PubMed Abstract | PubMed FullText

27. Fulda $S$ and Kroemer $G$. Targeting mitochondrial apoptosis by betulinic acid in human cancers. Drug Discov Today. 2009; 14:885-90. | Article | PubMed

28. Majeed R, Hamid A, Sangwan PL, Chinthakindi PK, Koul S, Rayees S, Singh G, Mondhe DM, Mintoo MJ, Singh SK, Rath SK and Saxena AK. Inhibition of phosphotidylinositol-3 kinase pathway by a novel naphthol derivative of betulinic acid induces cell cycle arrest and apoptosis in cancer cells of different origin. Cell Death Dis. 2014; 5:e1459. | Article | PubMed Abstract | PubMed FullText

29. Molad Y. Update on colchicine and its mechanism of action. Curr 
Gupta et al. Biochemical Compounds 2017,

Rheumatol Rep. 2002; 4:252-6. | Article | PubMed

30. Bhattacharyya B, Panda D, Gupta S and Banerjee M. Anti-mitotic activity of colchicine and the structural basis for its interaction with tubulin. Med Res Rev. 2008; 28:155-83. | Article | PubMed

31. Bachmeier BE, Mirisola V, Romeo F, Generoso L, Esposito A, Dell'eva $\mathrm{R}$, Blengio F, Killian PH, Albini A and Pfeffer U. Reference profile correlation reveals estrogen-like trancriptional activity of Curcumin. Cell Physiol Biochem. 2010; 26:471-82. | Article | PubMed

32. Senft C, Polacin M, Priester M, Seifert V, Kogel D and Weissenberger J. The nontoxic natural compound Curcumin exerts anti-proliferative, anti-migratory, and anti-invasive properties against malignant gliomas. BMC Cancer. 2010; 10:491. | Article | PubMed Abstract | PubMed FullText

33. Beevers CS, Chen L, Liu L, Luo Y, Webster NJ and Huang S. Curcumin disrupts the Mammalian target of rapamycin-raptor complex. Cancer Res. 2009; 69:1000-8. | Article | PubMed Abstract | PubMed FullText

34. Ravindran J, Prasad S and Aggarwal BB. Curcumin and cancer cells: how many ways can curry kill tumor cells selectively? AAPS J. 2009; 11:495510. | Article | PubMed Abstract | PubMed FullText

35. Johnson SM, Gulhati P, Arrieta I, Wang X, Uchida T, Gao T and Evers BM. Curcumin inhibits proliferation of colorectal carcinoma by modulating Akt/mTOR signaling. Anticancer Res. 2009; 29:3185-90. | Article | PubMed Abstract I PubMed FullText

36. Epstein J, Docena G, MacDonald TT and Sanderson IR. Curcumin suppresses p38 mitogen-activated protein kinase activation, reduces IL-1beta and matrix metalloproteinase- 3 and enhances IL-10 in the mucosa of children and adults with inflammatory bowel disease. $\mathrm{Br} J$ Nutr. 2010; 103:824-32. | Article | PubMed

37. Yu S, Shen G, Khor TO, Kim JH and Kong AN. Curcumin inhibits Akt/mammalian target of rapamycin signaling through protein phosphatase-dependent mechanism. Mol Cancer Ther. 2008; 7:260920. | Article | PubMed Abstract | PubMed FullText

38. Gutheil WG, Reed G, Ray A, Anant S and Dhar A. Crocetin: an agent derived from saffron for prevention and therapy for cancer. Curr Pharm Biotechnol. 2012; 13:173-9. | Article | PubMed Abstract | PubMed FullText

39. Amin A, Hamza AA, Daoud S, Khazanehdari K, Hrout AA, Baig B, Chaiboonchoe A, Adrian TE, Zaki N and Salehi-Ashtiani K. Saffron-Based Crocin Prevents Early Lesions of Liver Cancer: In vivo, In vitro and Network Analyses. Recent Pat Anticancer Drug Discov. 2016; 11:12133. | Article | PubMed

40. Samarghandian $\mathrm{S}$, Boskabady MH and Davoodi S. Use of in vitro assays to assess the potential antiproliferative and cytotoxic effects of saffron (Crocus sativus L.) in human lung cancer cell line. Pharmacogn Mag. 2011; 6:309-14.

41. Bakshi H, Sam S, Rozati R, Sultan P, Islam T, Rathore B, Lone Z, Sharma $M$, Triphati I and Saxena RC. DNA fragmentation and cell cycle arrest: a hallmark of apoptosis induced by Crocetin from kashmiri saffron in a human pancreatic cancer cell line. Asian Pac J Cancer Prev. 2010; 11:675-9.

42. Das I, Das $S$ and Saha T. Saffron suppresses oxidative stress in DMBAinduced skin carcinoma: A histopathological study. Acta Histochem. 2010; 112:317-27. | Article | PubMed

43. Aung HH, Wang CZ, Ni M, Fishbein A, Mehendale SR, Xie JT, Shoyama $\mathrm{CY}$ and Yuan CS. Crocetin from Crocus sativus possesses significant anti-proliferation effects on human colorectal cancer cells. Exp Oncol. 2007; 29:175-80.

44. Chryssanthi DG, Dedes PG, Karamanos NK, Cordopatis P and Lamari FN. Crocetin inhibits invasiveness of MDA-MB-231 breast cancer cells via downregulation of matrix metalloproteinases. Planta Med. 2011; 77:146-51. | Article | PubMed

45. Bathaie SZ and Mousavi SZ. New applications and mechanisms of action of saffron and its important ingredients. Crit Rev Food Sci Nutr. 2010; 50:761-86. | Article | PubMed

46. Kim JM, Kim JS, Yoo H, Choung MG and Sung MK. Effects of black soybean [Glycine max (L.) Merr.] seed coats and its anthocyanidins on colonic inflammation and cell proliferation in vitro and in vivo. J Agric
Food Chem. 2008; 56:8427-33. | Article | PubMed

47. Xu M, Bower KA, Wang S, Frank JA, Chen G, Ding M, Shi X, Ke Z and Luo J. Cyanidin-3-glucoside inhibits ethanol-induced invasion of breast cancer cells overexpressing ErbB2. Mol Cancer. 2010; 9:285. | Article | PubMed Abstract | PubMed FullText

48. Zikri NN, Riedl KM, Wang LS, Lechner J, Schwartz SJ and Stoner GD. Black raspberry components inhibit proliferation, induce apoptosis, and modulate gene expression in rat esophageal epithelial cells. Nutr Cancer. 2009; 61:816-26. | Article | PubMed Abstract | PubMed FullText

49. Kim JE, Kwon JY, Seo SK, Son JE, Jung SK, Min SY, Hwang MK, Heo YS, Lee KW and Lee HJ. Cyanidin suppresses ultraviolet B-induced COX-2 expression in epidermal cells by targeting MKK4, MEK1, and Raf-1. Biochem Pharmacol. 2010; 79:1473-82. | Article | PubMed

50. Lim TG, Kwon JY, Kim J, Song NR, Lee KM, Heo YS, Lee HJ and Lee KW. Cyanidin-3-glucoside suppresses B[a]PDE-induced cyclooxygenase-2 expression by directly inhibiting Fyn kinase activity. Biochem Pharmacol. 2011; 82:167-74. | Article | PubMed

51. Liou YF, Hall IH and Lee KH. Antitumor agents LIV: The effects of daphnoretin on in vitro protein synthesis of ehrlich as cites carcinoma cells and other tissues. J. Pharm. Sci. 1982; 71:745-9.

52. Acharya A, Das I, Singh $S$ and Saha T. Chemopreventive properties of indole-3-carbinol, diindolylmethane and other constituents of cardamom against carcinogenesis. Recent Pat Food Nutr Agric. 2010; 2:166-77. | Article | PubMed

53. Qian X, Melkamu T, Upadhyaya P and Kassie F. Indole-3-carbinol inhibited tobacco smoke carcinogen-induced lung adenocarcinoma in $\mathrm{A} / \mathrm{J}$ mice when administered during the post-initiation or progression phase of lung tumorigenesis. Cancer Lett. 2011; 311:57-65. | Article | PubMed Abstract | PubMed FullText

54. Bradlow HL and Zeligs MA. Diindolylmethane (DIM) spontaneously forms from indole-3-carbinol (I3C) during cell culture experiments. In Vivo. 2010; 24:387-91. | Article | PubMed

55. Banerjee S, Kong D, Wang Z, Bao B, Hillman GG and Sarkar FH. Attenuation of multi-targeted proliferation-linked signaling by 3,3'-diindolylmethane (DIM): from bench to clinic. Mutat Res. 2011; 728:47-66. | Article | PubMed Abstract | PubMed FullText

56. Saw $\mathrm{CL}$, Cintron $\mathrm{M}, \mathrm{Wu} \mathrm{TY}$, Guo $\mathrm{Y}$, Huang $\mathrm{Y}$, Jeong $\mathrm{WS}$ and Kong $\mathrm{AN}$. Pharmacodynamics of dietary phytochemical indoles $\mathrm{IBC}$ and DIM: Induction of Nrf2-mediated phase II drug metabolizing and antioxidant genes and synergism with isothiocyanates. Biopharm Drug Dispos. 2011; 32:289-300. | Article | PubMed Abstract | PubMed FullText

57. Lubet RA, Heckman BM, De Flora SL, Steele VE, Crowell JA, Juliana $\mathrm{MM}$ and Grubbs CJ. Effects of 5,6-benzoflavone, indole-3-carbinol (I3C) and diindolylmethane (DIM) on chemically-induced mammary carcinogenesis: is DIM a substitute for I3C? Oncol Rep. 2011; 26:731-6. | Article | PubMed

58. Wang TT, Schoene NW, Milner JA and Kim YS. Broccoli-derived phytochemicals indole-3-carbinol and 3,3'-diindolylmethane exerts concentration-dependent pleiotropic effects on prostate cancer cells: comparison with other cancer preventive phytochemicals. Mol Carcinog. 2012; 51:244-56. | Article | PubMed

59. Liu LF. DNA topoisomerase poisons as antitumor drugs. Annu Rev Biochem. 1989; 58:351-75. | Article | PubMed

60. Hsieh TC and Wu JM. Targeting CWR22Rv1 prostate cancer cell proliferation and gene expression by combinations of the phytochemicals EGCG, genistein and quercetin. Anticancer Res. 2009; 29:4025-32. | Article | PubMed Abstract | PubMed FullText

61. Qiao $Y, C a o ~ J, X i e ~ L$ and Shi $X$. Cell growth inhibition and gene expression regulation by (-)-epigallocatechin-3-gallate in human cervical cancer cells. Arch Pharm Res. 2009; 32:1309-15. | Article | PubMed

62. Philips BJ, Coyle CH, Morrisroe SN, Chancellor MB and Yoshimura N. Induction of apoptosis in human bladder cancer cells by green tea catechins. Biomed Res. 2009; 30:207-15. | Article | PubMed

63. Yang CS, Lambert JD, Ju J, Lu G and Sang S. Tea and cancer prevention: 
Gupta et al. Biochemical Compounds 2017,

http://www.hoajonline.com/journals/pdf/2052-9341-5-2.pdf

doi: $10.7243 / 2052-9341-5-2$

molecular mechanisms and human relevance. Toxicol Appl Pharmacol. 2007; 224:265-73. | Article | PubMed Abstract | PubMed FullText

64. Shimizu M, Shirakami Y, Sakai H, Adachi S, Hata K, Hirose Y, Tsurumi $\mathrm{H}$, Tanaka $\mathrm{T}$ and Moriwaki $\mathrm{H}$. (-)-Epigallocatechin gallate suppresses azoxymethane-induced colonic premalignant lesions in male C57BL/ KsJ-db/db mice. Cancer Prev Res (Phila). 2008; 1:298-304. | Article | PubMed

65. Adachi S, Shimizu M, Shirakami Y, Yamauchi J, Natsume H, Matsushima-Nishiwaki R, To S, Weinstein IB, Moriwaki H and Kozawa O. (-)-Epigallocatechin gallate downregulates EGF receptor via phosphorylation at Ser1046/1047 by $\mathrm{p} 38$ MAPK in colon cancer cells. Carcinogenesis. 2009; 30:1544-52. | Article | PubMed

66. Larsen CA and Dashwood RH. (-)-Epigallocatechin-3-gallate inhibits Met signaling, proliferation, and invasiveness in human colon cancer cells. Arch Biochem Biophys. 2010; 501:52-7. | Article | PubMed Abstract | PubMed FullText

67. Jamil S, Lam I, Majd M, Tsai SH and Duronio V. Etoposide induces cell death via mitochondrial-dependent actions of p53. Cancer Cell Int. 2015; 15:79. | Article | PubMed Abstract | PubMed FullText

68. Maher P, Dargusch R, Ehren JL, Okada S, Sharma K and Schubert D. Fisetin lowers methylglyoxal dependent protein glycation and limits the complications of diabetes. PLoS One. 2011; 6:e21226. | Article | PubMed Abstract | PubMed FullText

69. Geraets L, Haegens A, Brauers K, Haydock JA, Vernooy JH, Wouters $E F$, Bast $A$ and Hageman GJ. Inhibition of LPS-induced pulmonary inflammation by specific flavonoids. Biochem Biophys Res Commun. 2009; 382:598-603. | Article | PubMed

70. Lim DY and Park JH. Induction of $\mathbf{p} 53$ contributes to apoptosis of HCT-116 human colon cancer cells induced by the dietary compound fisetin. Am J Physiol Gastrointest Liver Physiol. 2009; 296:G1060-8. | Article | PubMed

71. Hanneken A, Lin FF, Johnson J and Maher P. Flavonoids protect human retinal pigment epithelial cells from oxidative-stress-induced death. Invest Ophthalmol Vis Sci. 2006; 47:3164-77. | Article I PubMed

72. Lee $\mathrm{SE}$, Jeong $\mathrm{SI}$, Yang $\mathrm{H}$, Park $\mathrm{CS}$, Jin $\mathrm{YH}$ and Park YS. Fisetin induces Nrf2-mediated HO-1 expression through PKC-delta and p38 in human umbilical vein endothelial cells. J Cell Biochem. 2011; 112:2352-60. | Article | PubMed

73. Khan N, Afaq F, Khusro FH, Mustafa Adhami V, Suh Y and Mukhtar H. Dual inhibition of phosphatidylinositol 3-kinase/Akt and mammalian target of rapamycin signaling in human nonsmall cell lung cancer cells by a dietary flavonoid fisetin. Int J Cancer. 2012; 130:1695-705. | Article | PubMed Abstract | PubMed FullText

74. Liao YC, Shih YW, Chao CH, Lee XY and Chiang TA. Involvement of the ERK signaling pathway in fisetin reduces invasion and migration in the human lung cancer cell line A549. J Agric Food Chem. 2009; 57:893341. | Article | PubMed

75. Shapiro GI. Preclinical and clinical development of the cyclindependent kinase inhibitor flavopiridol. Clin Cancer Res. 2004; 10:4270s-4275s. | Article | PubMed

76. Lopez-Lazaro M, Willmore E and Austin CA. Cells lacking DNA topoisomerase II beta are resistant to genistein. J Nat Prod. 2007; 70:763-7. | Article | PubMed

77. Wang W, Bringe NA, Berhow MA and Gonzalez de Mejia E. betaConglycinins among sources of bioactives in hydrolysates of different soybean varieties that inhibit leukemia cells in vitro. J Agric Food Chem. 2008; 56:4012-20. | Article | PubMed

78. Yamasaki M, Fujita S, Ishiyama E, Mukai A, Madhyastha H, Sakakibara $Y$, Suiko M, Hatakeyama K, Nemoto T, Morishita K, Kataoka H, Tsubouchi H and Nishiyama K. Soy-derived isoflavones inhibit the growth of adult T-cell leukemia cells in vitro and in vivo. Cancer Sci. 2007; 98:1740-6. | Article | PubMed

79. Raynal NJ, Momparler L, Charbonneau M and Momparler RL. Antileukemic activity of genistein, a major isoflavone present in soy products. J Nat Prod. 2008; 71:3-7. | Article | PubMed

80. Sanchez Y, Amran D, de Blas E and Aller P. Regulation of genisteininduced differentiation in human acute myeloid leukaemia cells
(HL60, NB4) Protein kinase modulation and reactive oxygen species generation. Biochem Pharmacol. 2009; 77:384-96. | Article | PubMed

81. Yang X, Yang S, McKimmey C, Liu B, Edgerton SM, Bales W, Archer LT and Thor AD. Genistein induces enhanced growth promotion in ERpositive/erbB-2-over expressing breast cancers by ERerbB-2 cross talk and p27/kip1 down regulation. Carcinogenesis. 2010; 31:695-702.

82. Seibel J, Molzberger AF, Hertrampf T, Laudenbach-Leschowski $U$ and Diel P. Oral treatment with genistein reduces the expression of molecular and biochemical markers of inflammation in a rat model of chronic TNBS-induced colitis. Eur J Nutr. 2009; 48:213-20. | Article | PubMed

83. Jeong $\mathrm{CH}$, Bode AM, Pugliese A, Cho YY, Kim HG, Shim JH, Jeon YJ, Li H, Jiang $\mathrm{H}$ and Dong $\mathrm{Z}$. [6]-Gingerol suppresses colon cancer growth by targeting leukotriene A4 hydrolase. Cancer Res. 2009; 69:5584-91. | Article | PubMed

84. Lee HS, Seo EY, Kang NE and Kim WK. [6]-Gingerol inhibits metastasis of MDA-MB-231 human breast cancer cells. J Nutr Biochem. 2008; 19:313-9. | Article | PubMed

85. Rhode J, Fogoros S, Zick S, Wahl H, Griffith KA, Huang J and Liu JR. Ginger inhibits cell growth and modulates angiogenic factors in ovarian cancer cells. BMC Complement Altern Med. 2007; 7:44. | Article | PubMed Abstract | PubMed FullText

86. Oyagbemi AA, Saba AB and Azeez OI. Molecular targets of [6]-gingerol: Its potential roles in cancer chemoprevention. Biofactors. 2010; 36:169-78. | Article | PubMed

87. Fresno $M$, Jimenez $A$ and Vazquez D. Inhibition of translation in eukaryotic systems by harringtonine. Eur J Biochem. 1977; 72:323-30. | Article | PubMed

88. Boyd MR, Burka LT, Wilson BJ and Sasame HA. In vitro studies on the metabolic activation of the pulmonary toxin, 4-ipomeanol, by rat lung and liver microsomes. J Pharmacol Exp Ther. 1978; 207:677-86. | Article | PubMed

89. Hazra B, Das Sarma M and Sanyal U. Separation methods of quinonoid constituents of plants used in Oriental traditional medicines. $J$ Chromatogr B Analyt Technol Biomed Life Sci. 2004; 812:259-75. | Article I PubMed

90. Cui Y, Morgenstern H, Greenland S, Tashkin DP, Mao JT, Cai L, Cozen W, Mack TM, Lu QY and Zhang ZF. Dietary flavonoid intake and lung cancer--a population-based case-control study. Cancer. 2008; 112:2241-8. | Article | PubMed

91. Gacche RN, Shegokar HD, Gond DS, Yang Z and Jadhav AD. Evaluation of selected flavonoids as antiangiogenic, anticancer, and radical scavenging agents: an experimental and in silico analysis. Cell Biochem Biophys. 2011; 61:651-63. | Article | PubMed

92. Calderon-Montano JM, Burgos-Moron E, Perez-Guerrero C and LopezLazaro M. A review on the dietary flavonoid kaempferol. Mini Rev Med Chem. 2011; 11:298-344. | Article | PubMed

93. Bigovic D, Savikin K, Jankovic T, Menkovic N, Zdunic G, Stanojkovic T and Djuric Z. Antiradical and cytotoxic activity of different Helichrysum plicatum flower extracts. Nat Prod Commun. 2011; 6:819-22. | PubMed

94. To KK, Yu L, Liu S, Fu J and Cho CH. Constitutive AhR activation leads to concomitant ABCG2-mediated multidrug resistance in cisplatinresistant esophageal carcinoma cells. Mol Carcinog. 2012; 51:449-64. | Article | PubMed

95. Luo H, Rankin GO, Li Z, Depriest $L$ and Chen YC. Kaempferol induces apoptosis in ovarian cancer cells through activating p53 in the intrinsic pathway. Food Chem. 2011; 128:513-519. | Article | PubMed Abstract | PubMed FullText

96. Giovannucci E, Ascherio A, Rimm EB, Stampfer MJ, Colditz GA and Willett WC. Intake of carotenoids and retinol in relation to risk of prostate cancer. J Nat/ Cancer Inst. 1995; 87:1767-76. | PubMed

97. Levy J, Bosin E, Feldman B, Giat Y, Miinster A, Danilenko M and Sharoni $Y$. Lycopene is a more potent inhibitor of human cancer cell proliferation than either alpha-carotene or beta-carotene. Nutr Cancer. 1995; 24:257-66. | Article | PubMed 
98. Nahum A, Hirsch K, Danilenko M, Watts CK, Prall OW, Levy J and Sharoni Y. Lycopene inhibition of cell cycle progression in breast and endometrial cancer cells is associated with reduction in cyclin D levels and retention of $\mathbf{p 2 7 ( K i p 1 ) ~ i n ~ t h e ~ c y c l i n ~ E - c d k 2 ~ c o m p l e x e s . ~ O n c o g e n e . ~}$ 2001; 20:3428-36. | Article | PubMed

99. Narisawa T, Fukaura $\mathrm{Y}$, Hasebe M, Ito M, Aizawa R, Murakoshi M, Uemura $\mathrm{S}$, Khachik $\mathrm{F}$ and Nishino $\mathrm{H}$. Inhibitory effects of natural carotenoids, alpha-carotene, beta-carotene, lycopene and lutein, on colonic aberrant crypt foci formation in rats. Cancer Lett. 1996; 107:137-42. | Article | PubMed

100. Canene-Adams K, Lindshield BL, Wang S, Jeffery EH, Clinton SK and Erdman JW, Jr. Combinations of tomato and broccoli enhance antitumor activity in dunning r3327-h prostate adenocarcinomas. Cancer Res. 2007; 67:836-43. | Article | PubMed

101. Mi Q, Cui B, Silva GL, Lantvit D, Lim E, Chai H, Hollingshead MG, Mayo JG, Kinghorn AD and Pezzuto JM. Pervilleines B and C, new tropane alkaloid aromatic esters that reverse the multidrug-resistance in the hollow fiber assay. Cancer Lett. 2002; 184:13-20. | Article | PubMed

102. Mi Q, Cui B, Lantvit D, Reyes-Lim E, Chai H, Pezzuto JM, Kinghorn AD and Swanson SM. Pervilleine F, a new tropane alkaloid aromatic ester that reverses multidrug resistance. Anticancer Res. 2003; 23:3607-15. | PubMed

103. Hahm ER and Singh SV. Bim contributes to phenethyl isothiocyanateinduced apoptosis in breast cancer cells. Mol Carcinog. 2012; 51:46574. | Article | PubMed Abstract | PubMed FullText

104. Moon YJ, Brazeau DA and Morris ME. Dietary phenethyl isothiocyanate alters gene expression in human breast cancer cells. Evid Based Complement Alternat Med. 2011; 2011. | Article | PubMed Abstract | PubMed FullText

105. Yan H, Zhu Y, Liu B, Wu H, Li Y, Wu X, Zhou Q and Xu K. Mitogenactivated protein kinase mediates the apoptosis of highly metastatic human non-small cell lung cancer cells induced by isothiocyanates. $\mathrm{Br}$ J Nutr. 2011; 106:1779-91. | Article | PubMed

106. Huong le D, Shim JH, Choi KH, Shin JA, Choi ES, Kim HS, Lee SJ, Kim SJ, Cho NP and Cho SD. Effect of beta-phenylethyl isothiocyanate from cruciferous vegetables on growth inhibition and apoptosis of cervical cancer cells through the induction of death receptors 4 and 5. J Agric Food Chem. 2011; 59:8124-31. | Article | PubMed

107. Wang X, Govind S, Sajankila SP, Mi L, Roy R and Chung FL. Phenethyl isothiocyanate sensitizes human cervical cancer cells to apoptosis induced by cisplatin. Mol Nutr Food Res. 2011; 55:1572-81. | Article | PubMed Abstract | PubMed FullText

108. Wu CL, Huang AC, Yang JS, Liao CL, Lu HF, Chou ST, Ma CY, Hsia TC, Ko YC and Chung JG. Benzyl isothiocyanate (BITC) and phenethyl isothiocyanate (PEITC)-mediated generation of reactive oxygen species causes cell cycle arrest and induces apoptosis via activation of caspase-3, mitochondria dysfunction and nitric oxide (NO) in human osteogenic sarcoma U-2 OS cells. J Orthop Res. 2011; 29:1199-209. | Article | PubMed

109. Xiao D, Powolny AA, Moura MB, Kelley EE, Bommareddy A, Kim SH, Hahm ER, Normolle D, Van Houten B and Singh SV. Phenethyl isothiocyanate inhibits oxidative phosphorylation to trigger reactive oxygen species-mediated death of human prostate cancer cells. J Biol Chem. 2010; 285:26558-69. | Article | PubMed Abstract | PubMed FullText

110. Hwang ES and Lee HJ. Effects of phenylethyl isothiocyanate and its metabolite on cell-cycle arrest and apoptosis in LNCaP human prostate cancer cells. Int J Food Sci Nutr. 2010; 61:324-36. | Article | PubMed

111. Powolny AA and Singh SV. Differential response of normal (PrEC) and cancerous human prostate cells (PC-3) to phenethyl isothiocyanatemediated changes in expression of antioxidant defense genes. Pharm Res. 2010; 27:2766-75. | Article | PubMed Abstract | PubMed FullText

112. Jakubikova J, Cervi D, Ooi M, Kim K, Nahar S, Klippel S, Cholujova D, Leiba M, Daley JF, Delmore J, Negri J, Blotta S, McMillin DW, Hideshima T, Richardson PG, Sedlak J, Anderson KC and Mitsiades CS. Anti-tumor activity and signaling events triggered by the isothiocyanates, sulforaphane and phenethyl isothiocyanate, in multiple myeloma. Haematologica. 2011; 96:1170-9. | Article | PubMed Abstract | PubMed FullText

113. Tang NY, Huang YT, Yu CS, Ko YC, Wu SH, Ji BC, Yang JS, Yang JL, Hsia TC, Chen YY and Chung JG. Phenethyl isothiocyanate (PEITC) promotes G2/M phase arrest via p53 expression and induces apoptosis through caspase- and mitochondria-dependent signaling pathways in human prostate cancer DU 145 cells. Anticancer Res. 2011; 31:1691-702. | Article | PubMed

114. Gao N, Budhraja A, Cheng S, Liu EH, Chen J, Yang Z, Chen D, Zhang Z and Shi $X$. Phenethyl isothiocyanate exhibits antileukemic activity in vitro and in vivo by inactivation of Akt and activation of JNK pathways. Cell Death Dis. 2011; 2:e140. | Article | PubMed Abstract | PubMed FullText

115. Bronikowska J, Szliszka E, Jaworska D, Czuba ZP and Krol W. The coumarin psoralidin enhances anticancer effect of tumor necrosis factor-related apoptosis-inducing ligand (TRAIL). Molecules. 2012; 17:6449-64. | Article | PubMed

116. Kim KH, Back JH, Zhu Y, Arbesman J, Athar M, Kopelovich L, Kim AL and Bickers DR. Resveratrol targets transforming growth factor-beta2 signaling to block UV-induced tumor progression. J Invest Dermatol. 2011; 131:195-202. | Article | PubMed Abstract | PubMed FullText

117. Nichols JA and Katiyar SK. Skin photoprotection by natural polyphenols: anti-inflammatory, antioxidant and DNA repair mechanisms. Arch Dermatol Res. 2010; 302:71-83. | Article | PubMed Abstract I PubMed FullText

118. Wu H, Liang X, Fang Y, Qin X, Zhang Y and Liu J. Resveratrol inhibits hypoxia-induced metastasis potential enhancement by restricting hypoxia-induced factor-1 alpha expression in colon carcinoma cells. Biomed Pharmacother. 2008; 62:613-21. I Article I PubMed

119. Sanchez-Fidalgo S, Cardeno A, Villegas I, Talero E and de la Lastra CA. Dietary supplementation of resveratrol attenuates chronic colonic inflammation in mice. Eur J Pharmacol. 2010; 633:78-84. | Article | PubMed

120. Jeong WS, Kim IW, Hu R and Kong AN. Modulation of AP-1 by natural chemopreventive compounds in human colon HT-29 cancer cell line. Pharm Res. 2004; 21:649-60. | PubMed

121. Xu Y, Xu G, Liu L, Xu D and Liu J. Anti-invasion effect of rosmarinic acid via the extracellular signal-regulated kinase and oxidation-reduction pathway in Ls174-T cells. J Cell Biochem. 2010; 111:370-9. | Article | PubMed

122. Xu Y, Jiang Z, Ji G and Liu J. Inhibition of bone metastasis from breast carcinoma by rosmarinic acid. Planta Med. 2010; 76:956-62. | Article | PubMed

123. Moon DO, Kim MO, Lee JD, Choi YH and Kim GY. Rosmarinic acid sensitizes cell death through suppression of TNF-alpha-induced NFkappaB activation and ROS generation in human leukemia U937 cells. Cancer Lett. 2010; 288:183-91. | Article | PubMed

124. Scheckel KA, Degner SC and Romagnolo DF. Rosmarinic acid antagonizes activator protein-1-dependent activation of cyclooxygenase-2 expression in human cancer and nonmalignant cell lines. J Nutr. 2008; 138:2098-105. | Article | PubMed Abstract | PubMed FullText

125. Meng LH and Ding J. Salvicine, a novel topoisomerase II inhibitor, exerts its potent anticancer activity by ROS generation. Acta Pharmacol Sin. 2007; 28:1460-5. | Article | PubMed

126. Kim S, Hwang BY, Su BN, Chai H, Mi Q, Kinghorn AD, Wild R and Swanson SM. Silvestrol, a potential anticancer rocaglate derivative from Aglaia foveolata, induces apoptosis in LNCaP cells through the mitochondrial/apoptosome pathway without activation of executioner caspase-3 or -7. Anticancer Res. 2007; 27:2175-83. I Article | PubMed Abstract | PubMed FullText

127. Li Y, Zhang T, Korkaya H, Liu S, Lee HF, Newman B, Yu Y, Clouthier SG, Schwartz SJ, Wicha MS and Sun D. Sulforaphane, a dietary component of broccoli/broccoli sprouts, inhibits breast cancer stem cells. Clin Cancer Res. 2010; 16:2580-90. | Article | PubMed Abstract | PubMed $\underline{\text { FullText }}$ 
Gupta et al. Biochemical Compounds 2017,

128. Rudolf $\mathrm{E}$, Andelova $\mathrm{H}$ and Cervinka M. Activation of several concurrent proapoptic pathways by sulforaphane in human colon cancer cells SW620. Food Chem Toxicol. 2009; 47:2366-73. | Article I PubMed

129. Rudolf $E$ and Cervinka M. Sulforaphane induces cytotoxicity and lysosome- and mitochondria-dependent cell death in colon cancer cells with deleted p53. Toxicol In Vitro. 2011; 25:1302-9. | Article | PubMed

130. Jeong WS, Keum YS, Chen C, Jain MR, Shen G, Kim JH, Li W and Kong AN. Differential expression and stability of endogenous nuclear factor E2-related factor $\mathbf{2}$ (Nrf2) by natural chemopreventive compounds in HepG2 human hepatoma cells. J Biochem Mol Biol. 2005; 38:167-76. | PubMed

131. Xu C, Shen G, Chen C, Gelinas C and Kong AN. Suppression of NFkappaB and NF-kappaB-regulated gene expression by sulforaphane and PEITC through IkappaBalpha, IKK pathway in human prostate cancer PC-3 cells. Oncogene. 2005; 24:4486-95. | Article I PubMed

132. Hu R, Xu C, Shen G, Jain MR, Khor TO, Gopalkrishnan A, Lin W, Reddy $B$, Chan JY and Kong AN. Gene expression profiles induced by cancer chemopreventive isothiocyanate sulforaphane in the liver of C57BL/6 J mice and C57BL/6J/Nrf2 (-/-) mice. Cancer Lett. 2006; 243:170-92. I Article | PubMed

133. Kim JH, Kim SH, Kolozsvary A and Khil MS. Potentiation of radiation response in human carcinoma cells in vitro and murine fibrosarcoma in vivo by topotecan, an inhibitor of DNA topoisomerase I. Int J Radiat Oncol Biol Phys. 1992; 22:515-8. I Article I PubMed

134. Bishayee A, Ahmed S, Brankov N and Perloff M. Triterpenoids as potential agents for the chemoprevention and therapy of breast cancer. Front Biosci (Landmark Ed). 2011; 16:980-96. | Article | PubMed Abstract | PubMed FullText

135. Gorham ED, Garland CF, Garland FC, Grant WB, Mohr SB, Lipkin M, Newmark HL, Giovannucci E, Wei M and Holick MF. Optimal vitamin D status for colorectal cancer prevention: a quantitative meta analysis. Am J Prev Med. 2007; 32:210-6. | Article | PubMed

136. Garland CF, Mohr SB, Gorham ED, Grant WB and Garland FC. Role of ultraviolet $B$ irradiance and vitamin $D$ in prevention of ovarian cancer. Am J Prev Med. 2006; 31:512-4. | Article | PubMed

137. Skinner HG, Michaud DS, Giovannucci E, Willett WC, Colditz GA and Fuchs CS. Vitamin D intake and the risk for pancreatic cancer in two cohort studies. Cancer Epidemiol Biomarkers Prev. 2006; 15:1688-95. | Article | PubMed

138. Chen WY, Bertone-Johnson ER, Hunter DJ, Willett WC and Hankinson $\mathrm{SE}$. Associations between polymorphisms in the vitamin D receptor and breast cancer risk. Cancer Epidemiol Biomarkers Prev. 2005; 14:2335-9. | Article | PubMed

139. Kovalenko PL, Zhang Z, Yu JG, Li Y, Clinton SK and Fleet JC. Dietary vitamin $D$ and vitamin $D$ receptor level modulate epithelial cell proliferation and apoptosis in the prostate. Cancer Prev Res (Phila). 2011; 4:1617-25. | Article | PubMed Abstract | PubMed FullText

140. Wada S. Cancer preventive effects of vitamin E. Curr Pharm Biotechnol. 2012; 13:156-64. | Article | PubMed

141. Chen ZL, Tao J, Yang J, Yuan ZL, Liu XH, Jin M, Shen ZQ, Wang L, Li HF, Qiu ZG, Wang JF, Wang XW and Li JW. Vitamin E modulates cigarette smoke extract-induced cell apoptosis in mouse embryonic cells. Int J Biol Sci. 2011; 7:927-36. | Article | PubMed Abstract | PubMed FullText

142. Nesaretnam $K$ and Meganathan P. Tocotrienols: inflammation and cancer. Ann N Y Acad Sci. 2011; 1229:18-22. I Article I PubMed

143. Shin-Kang S, Ramsauer VP, Lightner J, Chakraborty K, Stone W, Campbell S, Reddy SA and Krishnan K. Tocotrienols inhibit AKT and ERK activation and suppress pancreatic cancer cell proliferation by suppressing the ErbB2 pathway. Free Radic Biol Med. 2011; 51:116474. I Article I PubMed

144. Zhang FL, Wang P, Liu YH, Liu LB, Liu XB, Li Z and Xue YX. Topoisomerase $I$ inhibitors, shikonin and topotecan, inhibit growth and induce apoptosis of glioma cells and glioma stem cells. PLoS One. 2013; 8:e81815. | Article | PubMed Abstract | PubMed FullText

145. Chiu WH, Luo SJ, Chen CL, Cheng JH, Hsieh CY, Wang CY, Huang WC, Su WC and Lin CF. Vinca alkaloids cause aberrant ROS-mediated
JNK activation, Mcl-1 downregulation, DNA damage, mitochondrial dysfunction, and apoptosis in lung adenocarcinoma cells. Biochem Pharmacol. 2012; 83:1159-71. | Article | PubMed

146. Li-Weber M. Targeting apoptosis pathways in cancer by Chinese medicine. Cancer Lett. 2013; 332:304-12. I Article I PubMed

147. Lemasters JJ, Theruvath TP, Zhong Z and Nieminen AL. Mitochondrial calcium and the permeability transition in cell death. Biochim Biophys Acta. 2009; 1787:1395-401. | Article | PubMed Abstract | PubMed FullText

148. Fesik SW and Shi Y. Structural biology. Controlling the caspases. Science. 2001; 294:1477-8. | Article | PubMed

149. Dejean LM, Martinez-Caballero S, Manon S and Kinnally KW. Regulation of the mitochondrial apoptosis-induced channel, MAC, by BCL-2 family proteins. Biochim Biophys Acta. 2006; 1762:191-201. | Article | PubMed

150. Dejean LM, Martinez-Caballero S and Kinnally KW. Is MAC the knife that cuts cytochrome $\mathrm{c}$ from mitochondria during apoptosis? Cell Death Differ. 2006; 13:1387-95. | Article | PubMed

151. Wajant $\mathrm{H}$. The Fas signaling pathway: more than a paradigm. Science. 2002; 296:1635-6. | Article | PubMed

152. Negrini S, Gorgoulis VG and Halazonetis TD. Genomic instability-an evolving hallmark of cancer. Nat Rev Mol Cell Biol. 2010; 11:220-8.

153. Luijsterburg MS and van Attikum H. Chromatin and the DNA damage response: the cancer connection. Mol Oncol. 2011; 5:349-67. | Article I PubMed

154. Sheehan KM, Sheahan K, O'Donoghue DP, MacSweeney F, Conroy RM, Fitzgerald DJ and Murray FE. The relationship between cyclooxygenase-2 expression and colorectal cancer. Jama. 1999; 282:1254-7.

155. Romagnolo DF, Papoutsis AJ and Selmin O. Nutritional targeting of cyclooxygenase-2 for colon cancer prevention. Inflamm Allergy Drug Targets. 2010; 9:181-91. | Article | PubMed

156. Surh YJ and Kundu JK. Signal transduction network leading to COX-2 induction: a road map in search of cancer chemopreventives. Arch Pharm Res. 2005; 28:1-15. | PubMed

157. Chun KS and Surh YJ. Signal transduction pathways regulating cyclooxygenase-2 expression: potential molecular targets for chemoprevention. Biochem Pharmacol. 2004; 68:1089-100. | Article | PubMed

158. Chen JK, Taipale J, Young KE, Maiti T and Beachy PA. Small molecule modulation of Smoothened activity. Proc Natl Acad Sci U S A. 2002; 99:14071-6. | Article | PubMed Abstract | PubMed FullText

159. Taipale J, Cooper MK, Maiti T and Beachy PA. Patched acts catalytically to suppress the activity of Smoothened. Nature. 2002; 418:892-7. | Article I PubMed

160. Sarkar FH, Li Y, Wang $\mathrm{Z}$ and Kong D. The role of nutraceuticals in the regulation of Wnt and Hedgehog signaling in cancer. Cancer Metastasis Rev. 2010; 29:383-94. | Article | PubMed Abstract | PubMed FullText

161. Marini KD, Payne BJ, Watkins DN and Martelotto LG. Mechanisms of Hedgehog signalling in cancer. Growth Factors. 2011; 29:221-34. | Article I PubMed

162. Gupta S, Takebe $\mathrm{N}$ and Lorusso P. Targeting the Hedgehog pathway in cancer. Ther Adv Med Oncol. 2010; 2:237-50. I Article I PubMed Abstract | PubMed FullText

163. Stecca B, Mas C and Ruiz i Altaba A. Interference with HH-GLI signaling inhibits prostate cancer. Trends Mol Med. 2005; 11:199-203. | Article | PubMed

164. Nelson DE, Ihekwaba AE, Elliott $M$, Johnson JR, Gibney CA, Foreman BE, Nelson G, See V, Horton CA, Spiller DG, Edwards SW, McDowell HP, Unitt JF, Sullivan E, Grimley R, Benson N, Broomhead D, Kell DB and White MR. Oscillations in NF-kappaB signaling control the dynamics of gene expression. Science. 2004; 306:704-8. I Article I PubMed

165. Escarcega RO, Fuentes-Alexandro S, Garcia-Carrasco M, Gatica A and Zamora A. The transcription factor nuclear factor-kappa B and cancer. Clin Oncol (R Coll Radiol). 2007; 19:154-61. I PubMed 
166. Moi P, Chan K, Asunis I, Cao A and Kan YW. Isolation of NF-E2-related factor 2 (Nrf2), a NF-E2-like basic leucine zipper transcriptional activator that binds to the tandem NF-E2/AP1 repeat of the betaglobin locus control region. Proc Natl Acad Sci U S A. 1994; 91:9926-30. | Article | PubMed Abstract | PubMed FullText

167. Itoh K, Wakabayashi N, Katoh Y, Ishii T, Igarashi K, Engel JD and Yamamoto M. Keap1 represses nuclear activation of antioxidant responsive elements by Nrf2 through binding to the amino-terminal Neh2 domain. Genes Dev. 1999; 13:76-86. | Article | PubMed Abstract I PubMed FullText

168. Li W and Kong AN. Molecular mechanisms of Nrf2-mediated antioxidant response. Mol Carcinog. 2009; 48:91-104. | Article | PubMed Abstract | PubMed FullText

169. Venugopal R and Jaiswal AK. Nrf1 and Nrf2 positively and c-Fos and Fra1 negatively regulate the human antioxidant response elementmediated expression of NAD(P)H:quinone oxidoreductase1 gene. Proc Natl Acad Sci U S A. 1996; 93:14960-5. | Article | PubMed Abstract | PubMed FullText

170. Solis WA, Dalton TP, Dieter MZ, Freshwater S, Harrer JM, He L, Shertzer HG and Nebert DW. Glutamate-cysteine ligase modifier subunit: mouse Gclm gene structure and regulation by agents that cause oxidative stress. Biochem Pharmacol. 2002; 63:1739-54. | Article | PubMed

171. Hayes JD, Chanas SA, Henderson CJ, McMahon M, Sun C, Moffat GJ, Wolf $C R$ and Yamamoto $M$. The Nrf2 transcription factor contributes both to the basal expression of glutathione S-transferases in mouse liver and to their induction by the chemopreventive synthetic antioxidants, butylated hydroxyanisole and ethoxyquin. Biochem Soc Trans. 2000; 28:33-41. | Article I PubMed

172. Yueh MF and Tukey RH. Nrf2-Keap1 signaling pathway regulates human UGT1A1 expression in vitro and in transgenic UGT1 mice. J Biol Chem. 2007; 282:8749-58. | Article | PubMed

173. Maher JM, Dieter MZ, Aleksunes LM, Slitt AL, Guo G, Tanaka Y, Scheffer GL, Chan JY, Manautou JE, Chen Y, Dalton TP, Yamamoto M and Klaassen $C D$. Oxidative and electrophilic stress induces multidrug resistance-associated protein transporters via the nuclear factor-E2related factor-2 transcriptional pathway. Hepatology. 2007; 46:1597610. | Article | PubMed

174. Kalaany NY and Sabatini DM. Tumours with PI3K activation are resistant to dietary restriction. Nature. 2009; 458:725-31. | Article | PubMed Abstract | PubMed FullText

175. Klampfer L. Signal transducers and activators of transcription (STATs): Novel targets of chemopreventive and chemotherapeutic drugs. Curr Cancer Drug Targets. 2006; 6:107-21. | Article I PubMed

176. Lie DC, Colamarino SA, Song HJ, Desire L, Mira H, Consiglio A, Lein ES, Jessberger S, Lansford H, Dearie AR and Gage FH. Wnt signalling regulates adult hippocampal neurogenesis. Nature. 2005; 437:1370-5. | Article | PubMed

177. Nelson WJ and Nusse R. Convergence of Wnt, beta-catenin, and cadherin pathways. Science. 2004; 303:1483-7. | Article | PubMed Abstract | PubMed FullText

178. MacDonald BT, Tamai $\mathrm{K}$ and $\mathrm{He} X$. Wnt/beta-catenin signaling: components, mechanisms, and diseases. Dev Cell. 2009; 17:9-26. | Article | PubMed Abstract | PubMed FullText

179. Menendez JA, Vazquez-Martin A, Garcia-Villalba R, Carrasco-Pancorbo A, Oliveras-Ferraros C, Fernandez-Gutierrez A and Segura-Carretero A. tabAnti-HER2 (erbB-2) oncogene effects of phenolic compounds directly isolated from commercial Extra-Virgin Olive Oil (EVOO). BMC Cancer. 2008; 8:377. | Article | PubMed Abstract | PubMed FullText

180. Palozza $P$, Colangelo $M$, Simone $R$, Catalano A, Boninsegna A, Lanza $P$, Monego $G$ and Ranelletti FO. Lycopene induces cell growth inhibition by altering mevalonate pathway and Ras signaling in cancer cell lines. Carcinogenesis. 2010; 31:1813-21. | Article | PubMed

181. Bishayee $A$ and Sethi G. Bioactive natural products in cancer prevention and therapy: Progress and promise. Semin Cancer Biol. 2016; 40-41:1-3. | Article | PubMed

\section{Citation:}

Gupta VK, Singh R and Sharma B. Phytochemicals mediated signalling pathways and their

implications in cancer chemotherapy: Challenges and opportunities in phytochemicals based drug development: A review. Bio Chem Comp. 2017; 5:2. http://dx.doi.org/10.7243/2052-9341-5-2 